\title{
Effect of weather on the abundance of winter eggs of the European red spider mite on apple
}

\author{
TUOMO TUOVINEN
}

\begin{abstract}
TUOVINEN, T. 1992. Effect of weather on the abundance of winter eggs of the European red spider mite on apple. Agric. Sci. Finl. 1: 83-93. (Agric. Res. Centre of Finland, Inst. PI. Protect., SF-31600 Jokioinen, Finland).

Winter eggs of the European red spider mite Panonychus ulmi were counted on apple twig samples $(\mathrm{N}=279)$ collected in south-western Finland in the winters of 1984/85 through 1989/90. The results of the counts were analyzed to determine the effect of the regional temperature and precipitation during the preceding growing season on the abundance of overwintering spider mite eggs.

The total effective temperature sum of the growing seasons in day-degrees over $+5{ }^{\circ} \mathrm{C}$ varied between 1030 and 1564 and the total precipitation between 289 and 562 $\mathrm{mm}$ in May - October. The number of $P$. ulmi winter eggs in commercial orchards correlated positively with the sum of day-degrees in August, July, June and during the entire growing period. There were negative correlations between the numbers of $P$. ulmi winter eggs and the precipitation in May, October, August and in the entire growing season. The cold winters of 1985 (min. temp. - $36.7^{\circ} \mathrm{C}$ ) and $1987\left(-34.0^{\circ} \mathrm{C}\right.$ ) reduced the percentage of winter egg hatching to 23 and $56.5 \%$, respectively, compared to the mean hatching rate of $75-77 \%$ in 1986 and 1988 . The value of weather records to facilitate the prognosis of need of early spring sprays against $P$. ulmi is discussed.
\end{abstract}

Key words: European red spider mite, Panonychus ulmi, effect of weather, prognosis

\section{Introduction}

The European red spider mite (ERM) Panonychus ulmi (Koch) (Acari: Tetranychidae) causes damage in apple orchards especially during warm, dry seasons. In Finland, ERM normally has three or four generations, in warm summers even an incomplete fifth generation may occur (LisTo et al. 1939). In addition to temperature, humidity and rain affect mite populations. VeERMAN (1985) mention that ERM winter egg hatch is greatly reduced in very high or low relative humidities during incubation. PutMan (1970) noticed a delay in development as well as an increase in mortality of ERM summer eggs in relative humidities above $92 \%$.

The relatively short growing season typical of
Finland restricts the increase of ERM compared to temperate zones. On the other hand, unusually warm periods may result in unexpected mite outbreaks. In Finland, the effective temperature sums of growing seasons in day-degrees over +5 ${ }^{\circ} \mathrm{C}$ may vary even by $50 \%$ between two successive years. A difference of this size can be expected to have a major effect on the reproduction rate of the mites. Besides summer temperature, changes in minimum winter temperatures may affect the viability of ERM winter eggs. Extremely low winter temperatures increase the mortality of ERM winter eggs (LIENK and CHAPMAN 1958, MACPHEE 1961, SøмME 1965, 1966). Especially in Finland, where the minimum temperatures may fall below $30^{\circ} \mathrm{C}$, winter mortality may be of great importance. 
In addition to the climatic factors, cultural measures may either increase or reduce the ERM density. Acaricidal sprays reduce mite numbers but, on the other hand, broad-spectrum insecticides affect natural enemies and, consequently, allow faster ERM population growth (MCMURTRY et al. 1970, CROFT and BROWN 1975). Intensive cultivation together with pruning and use of fertilizers tend to result in higher ERM densities (PosT 1962). These techniques are applied more intensively in commercial orchards than in home gardens, and their influence on ERM densities can be seen in comparisons between commercial and home gardens also in Finland (KROPCZYNSKA and TUOVINEN 1988).

This report is part of a study which was initiated to develop integrated mite management methods for Finnish growers. One purpose of the study was to determine methods for estimating ERM densities in winter and during the season. The samples collected for purposes of estimation were used to evaluate the effect of temperature and precipitation on the numbers of ERM winter eggs. The aim of this report is to determine the relationship between weather and ERM winter egg abundance, to be used for prior rough estimates of ERM.

\section{Material and methods}

Apple twig samples were collected in NovemberMarch in the winters 1984/85 through 1989/90 from 6-34 orchards every year. Each sample consisted of 20 pieces of 10-20 cm twigs of the same cultivar, cut randomly from two-year-old branches, one twig/ tree. Sampling was done by growers, and they were advised to collect twigs throughout the whole field. 16-72 samples were inspected every year, and the total number of samples was 279 . For egg counts, a $10 \mathrm{~cm}$ piece was cut from the top end of each twig,

\section{DAY-DEGREES}
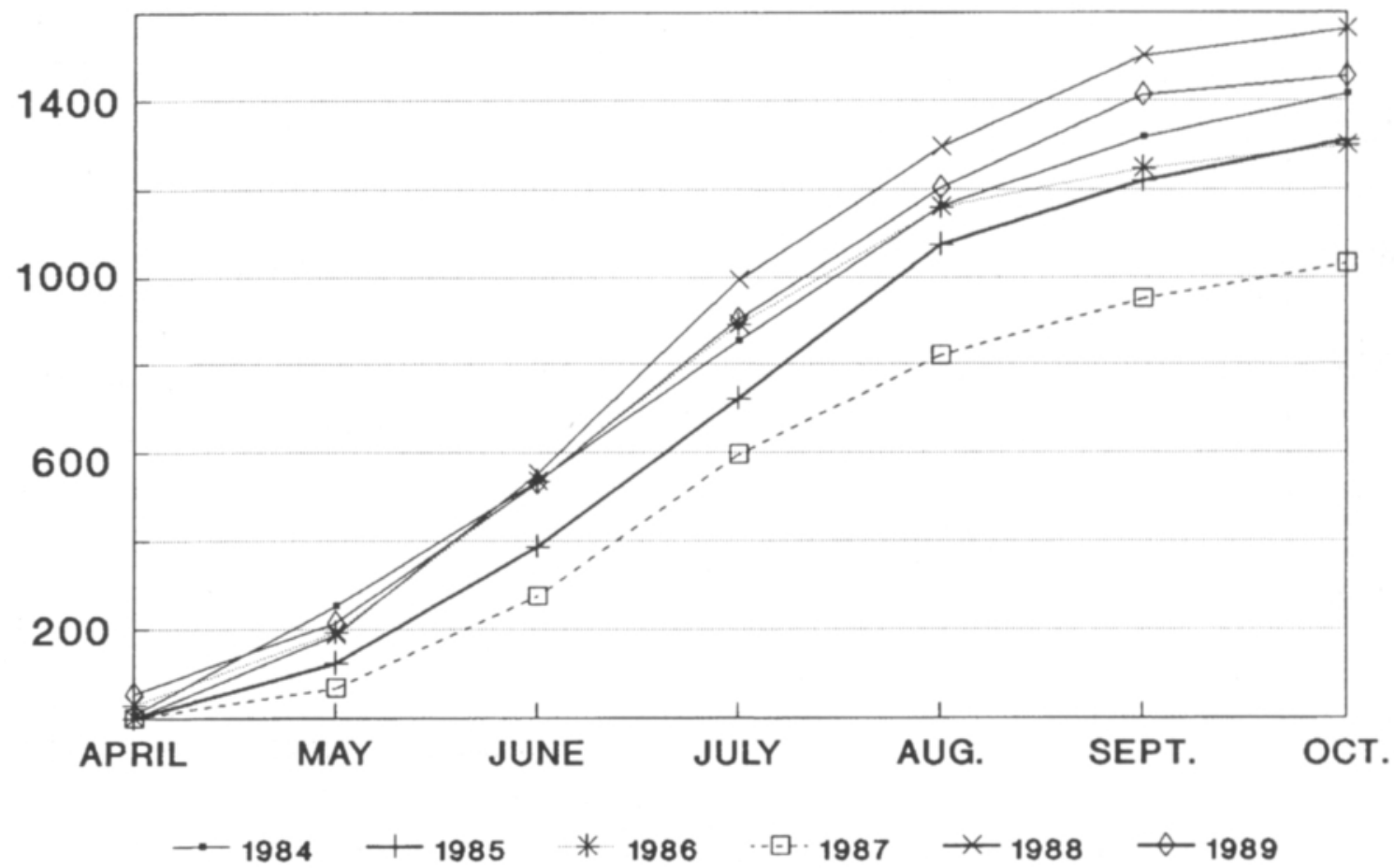

Fig. 1. Cumulative sums of monthly day-degrees above $+5^{\circ} \mathrm{C}$ in Piikkiö in 1984-1989. 
including at least one branch base. The number of undamaged, red ERM winter eggs was counted under a stereomicroscope.

The viability of overwintered eggs was checked in $1985-1988$ by incubating samples from several orchards in the laboratory at $+20 /+15{ }^{\circ} \mathrm{C}, 75 \pm 10 \%$ $\mathrm{Rh}$ under a light/dark regime of 13/11 h (cf. TUOVINEN 1990). In 1984/85 and 1986/87, unusually low winter temperatures were recorded, and samples were taken at different dates before and after the cold periods (Fig. 3).

Weather data were obtained from Piikkiö weather station $\left(60^{\circ} 23^{\prime} \mathrm{N}, 22^{\circ} 33^{\prime} \mathrm{E}\right)$, which was chosen as the most representative meteorological station for the whole apple growing area. All the commercial study orchards are situated inside an $85 \mathrm{~km}$ radius from Piikkiö (excluding the samples from Åland). The following weather parameters were chosen, and the correlation with the ERM winter egg density on branches in the autumn was analysed:

1) effective temperature sum over $+5{ }^{\circ} \mathrm{C}$ (= daydegrees) during the growing season,

2) sum of day-degrees in May-October (Fig. 1),

3) total precipitation during the growing season, and

4) precipitation in May-October (Fig. 2).

Other factors considered in the study were the origin (orchard) of the samples, the apple cultivars and the number of fungicidal, insecticidal and acaricidal sprays (Table 1). In individual orchards, the number of pesticide sprays did not vary much from year to year, but there were some changes in the profile of the pesticides used during the study period.

For the analyses of weather factors, only the data from commercial orchards on the mainland $(\mathrm{N}=209)$ were included. From these orchards, samples of the cultivars 'Lobo' and 'Kaneli' were most numerous. The data from unsprayed small

\section{MM}

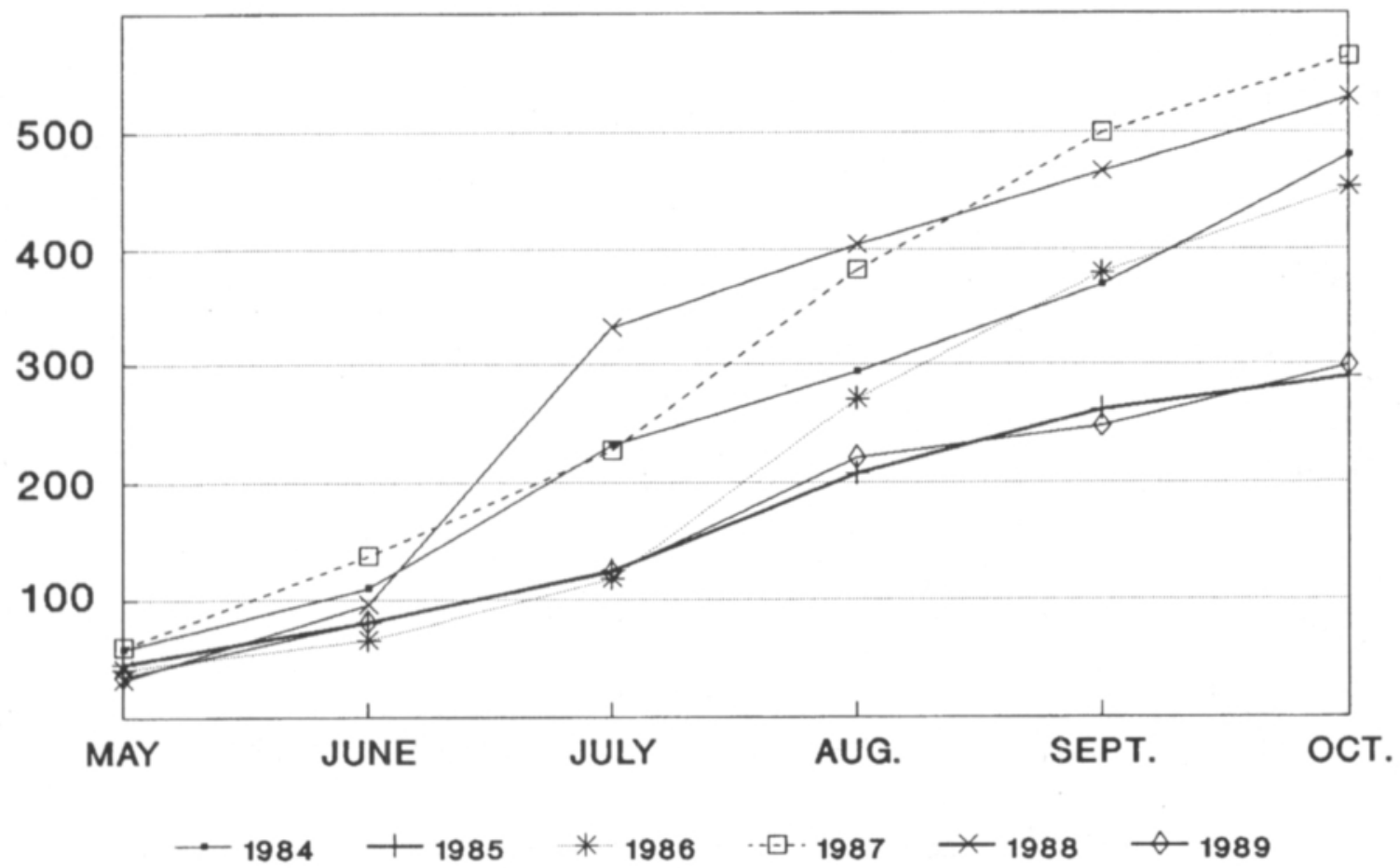

Fig. 2. Cumulative sums of monthly precipitation in Piikkiö in 1984-1989. 
a

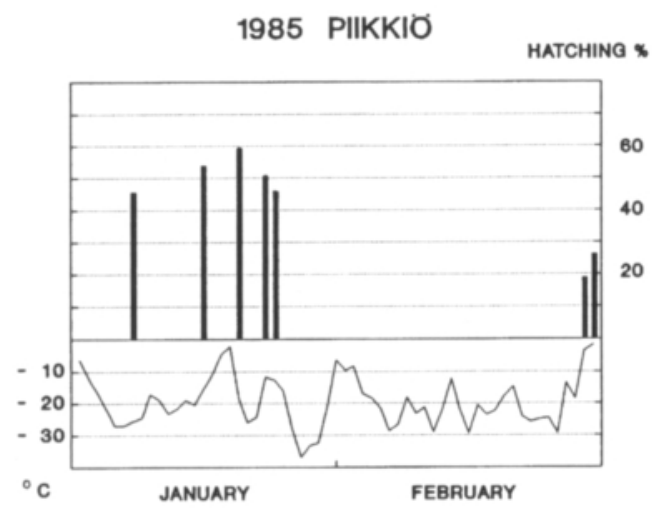

b

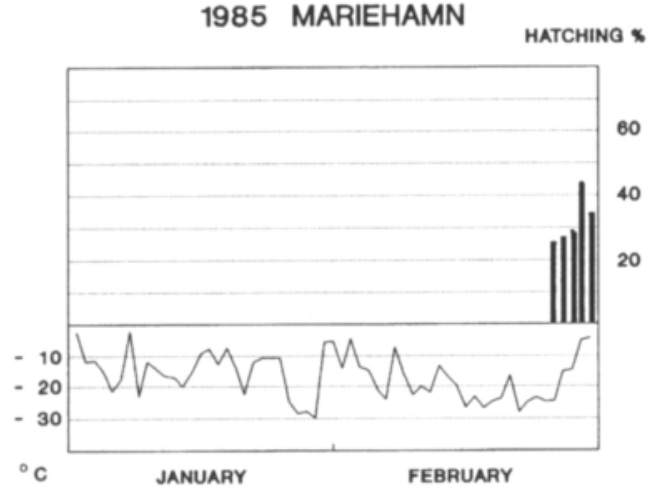

C

1987 PIIKKIO

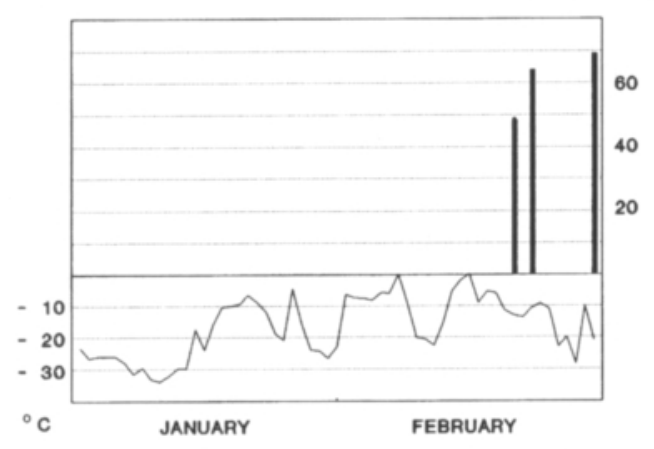

Fig. 3. Daily minimum temperatures and hatching percentages of ERM winter eggs collected on different dates in 1985 and 1987 in Piikkiö (a, c) and in Åland (b). Each vertical bar represents 1-3 localities from which samples were collected on the given date in the mainland (a, c) or in Åland (b). gardens $(\mathrm{N}=50)$ were excluded, because in these gardens either no or only very few ERM eggs were found. The samples from Aland $(\mathrm{N}=20)$ were also excluded because the island represents a different climatic area, and the number of samples was too small for separate analyses.

The origin and number of samples varied depending on the year. To exclude the effect of orchards and cultivars in weather analyses, regression analyses were made using the relative change in ERM winter egg numbers in two subsequent years from the same orchards and cultivars as a dependent variable, and weather parameters were calculated as relative changes between the same years. Hence, the analyses included the following terms: relative change in a weather factor $=100 *$ wf $[$ year(x)] $/$ wf $[\operatorname{year}(x-1)]$; relative change in ERM winter eggs $=100^{*}$ ERM[year(x)] / ERM[year(x-1)]. The effect of pesticide sprays was analyzed by the Pearson correlation analysis using the data as such.

\section{Results}

The effective temperature sums in August, July, June and in the whole growing period showed a significant positive correlation with ERM winter egg numbers when all commercial orchards, Åland excluded, were taken into account (Table 2).

The monthly precipitations in May, August and October showed significant negative correlations with ERM winter egg numbers (Table 2). The correlation of total precipitation in May-October was also significant, although not so evident.

The numbers of ERM winter eggs varied in commercial, sprayed orchards depending on the orchards and cultivars, with quite a wide range of ERM winter egg numbers (Fig. 4). In the peak year of 1985/86, the range of ERM numbers was 2-837, and in other years the following minimum and maximum values were recorded: 1984/85: 0-249; 1986/87: 1-561; 1987/88: 0-139, 1988/89: 3-354; and 1989/90: 8-343. In unsprayed samples from small home orchards, not included in Fig. 4, the ERM winter egg numbered as a rule less than 10 
Table 1. Mean numbers of pesticide sprays in $1984-1989$ in commercial orchards $(\mathrm{N}=$ number of samples).

\begin{tabular}{rllllll} 
& 1984 & 1985 & 1986 & 1987 & 1988 & 1989 \\
\hline $\mathrm{N}=$ & 64 & 40 & 36 & 41 & 39 & 16 \\
Insecticides $^{1)}$ & 3.7 & 3.3 & 2.9 & 2.5 & 2.5 & 2.1 \\
Acaricides $^{2)}$ & 1.3 & 1.4 & 1.7 & 1.2 & 1.1 & 1.5 \\
Fungicides $^{3)}$ & 5.5 & 5.3 & 6.6 & 5.6 & 5.3 & 7.2 \\
\hline Total $^{\text {Tot }}$ & 10.4 & 9.9 & 11.2 & 9.3 & 8.9 & 10.8 \\
\hline
\end{tabular}

1) azinphosmethyl, cypermethrin, deltamethrin, dimethoate, fenitrothion, malathion, oxydemetonmethyl, parathionethyl, pyrethrin

${ }^{2)}$ chinomethionate, chlorbenzilate, dicofol, fenson, flubenzimine, hexythiazox, paraffin oil, tar oil

${ }^{3)}$ bitertanol, captan, dichlofluanid, dinocap, dithianon, thiram, triforin

Table 2. Regression coefficients of the relative changes in monthly effective temperature sums and monthly precipitations to numbers of ERM winter eggs. Results of regression analyses of data from commercial orchards (total $N=209$ ), from five orchards from which a continuous series of data was available (total $\mathrm{N}=82$ ) and from a single orchard including five cultivars (total $\mathrm{N}=30$ ).

\begin{tabular}{llll}
\hline & Comm. & Five & Single \\
orchard \\
Weather & $\mathrm{N}=91$ & orchards & $\mathrm{N}=25$ \\
parameter & $\mathrm{r}$ & $\mathrm{N}=62$ & $\mathrm{r}$ \\
\hline
\end{tabular}

Day-degrees in:

$\begin{array}{lccr}\text { May } & 0.17 \mathrm{~ns} & 0.35^{* *} & 0.12 \mathrm{~ns} \\ \text { June } & 0.21^{*} & 0.37^{* *} & 0.23 \mathrm{~ns} \\ \text { July } & 0.33^{* *} & 0.49^{* * *} & 0.43^{*} \\ \text { August } & 0.38^{* * *} & 0.54^{* * *} & 0.62^{* *} \\ \text { September } & 0.10 \mathrm{~ns} & 0.22 \mathrm{~ns} & 0.04 \mathrm{~ns} \\ \text { October } & -0.07 \mathrm{~ns} & -0.07 \mathrm{~ns} & -0.10 \mathrm{~ns} \\ & & & 0.28 \mathrm{~ns}\end{array}$

Precipitation in:

\begin{tabular}{lccc} 
May & $-0.33^{* *}$ & $-0.48^{* * *}$ & $-0.57^{* *}$ \\
June & $-0.18 \mathrm{~ns}$ & $-0.22 \mathrm{~ns}$ & $-0.37 \mathrm{~ns}$ \\
July & $0.07 \mathrm{~ns}$ & $0.24 \mathrm{~ns}$ & $-0.06 \mathrm{~ns}$ \\
August & $-0.22^{*}$ & $-0.37^{* *}$ & $-0.24 \mathrm{~ns}$ \\
September & $-0.19 \mathrm{~ns}$ & $-0.23 \mathrm{~ns}$ & $-0.30 \mathrm{~ns}$ \\
October & $-0.29^{* *}$ & $-0.39^{* *}$ & $-0.72^{* * *}$ \\
& & $-0.23 \mathrm{~ns}$ & $-0.46^{*}$ \\
\hline
\end{tabular}


eggs $/ 10 \mathrm{~cm}$ twig. In these samples the differences between years were small; other than year-bound climatic factors obviously control the ERM numbers in the nearly 'natural' conditions that prevail in small gardens. These unsprayed gardens were therefore excluded from the analyses. In commercial orchards, the differences in the mean ERM numbers between years were about three-fold during the study period, and the greatest difference for one cultivar between two subsequent years was about four-fold (Fig. 4). When only the data from five cultivars in one orchard were considered, the differences between years were more distinct (Fig. 5).

Low winter temperatures, especially in 1985 but also in 1987 , caused a reduction in the viability of
ERM winter eggs (Fig. 3). In 1985, samples from different orchards were incubated before and after the cold period. In January, the hatching rate was quite low, only $49.4 \%$ (S.D. $=12.8, \mathrm{~N}=21$ ) even before the extremely cold period at the end of January, and in February, after the cold period, only $23 \%$ (S.D. = 3.6, N = 3). In Åland, where the lowest temperature in 1985 was $-29.7{ }^{\circ} \mathrm{C}$, the viability of eggs at the end of February was $35.5 \%$ $($ S.D. $=9.2, \mathrm{~N}=6$ ). In $1986 / 87$, the viability of ERM winter eggs was studied in the autumn (November 10) before severe frosts. There was a significant difference in the viability of eggs in the autumn, $72.0 \%$, and after the winter, $56.5 \%$ (Student's t-test, $\mathrm{P}<0.001$ ).In 1986 and 1988, with

\section{ERM EGGS}
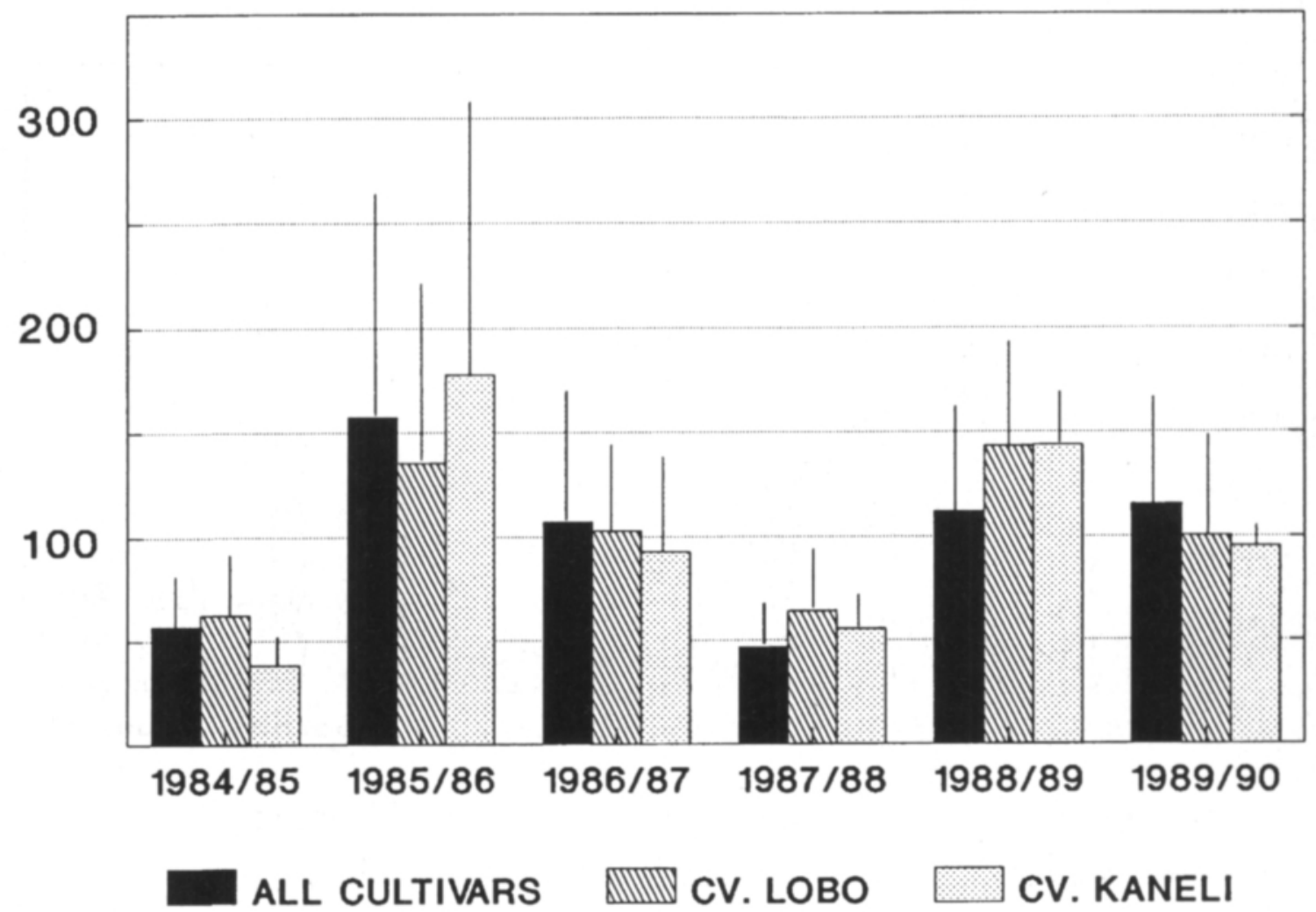

CV. KANELI

Fig. 4. Numbers of ERM winter eggs/10 cm twig in the winters $1984 / 85$ through $1989 / 90$ in commercial orchards. The vertical bars indicate the standard deviations of samples. 
minimum temperatures of -29.5 and $-24.6{ }^{\circ} \mathrm{C}$, the hatching percentages were 75.0 (S.D. 2.6, $\mathrm{N}=4$ ) and $77.6 \%($ S.D. $=6.5, \mathrm{~N}=5)$, respectively, when determined in the beginning of March.

The number of pesticide sprays in commercial orchards did not vary much in 1984-89 (Table 1). In all orchards, the number of acaricidal sprays correlated positively with the number of ERM winter eggs, but the correlation was very small (Table 3). The total number of pesticide sprays, as well as fungicides or insecticides separately, showed more distinct correlations with ERM winter egg numbers. In commercial orchards, a higher number of insecticidal and/or fungicidal sprays was reflected in greater ERM densities, but the effect of the acaricidal sprays was not significant. In 1985-88, most frequently in 1987, a new acaricide, flubenzimine (Bayer AG), was applied in some of the orchards. In control experiments, this acaricide appeared to be effective (TuOvinEN 1989). However, the effect of this acaricide in 1987 on the overwintering ERM density appeared not to be noticeable. The mean number of ERM winter eggs $/ 10 \mathrm{~cm}$ twig on flubenzimine-treated trees was $173.9(\mathrm{~N}=$ $3)$ in 1986 and $66.6(\mathrm{~N}=22)$ in 1987 , and on nonflubenzimine-treated trees $99.8(\mathrm{~N}=33)$ and $37.8(\mathrm{~N}$ $=19$ ), respectively. The relative change in ERM winter egg numbers between the two years was about the same in both groups of orchards. - It is assumed that the relatively poor results with

\section{ERM EGGS}

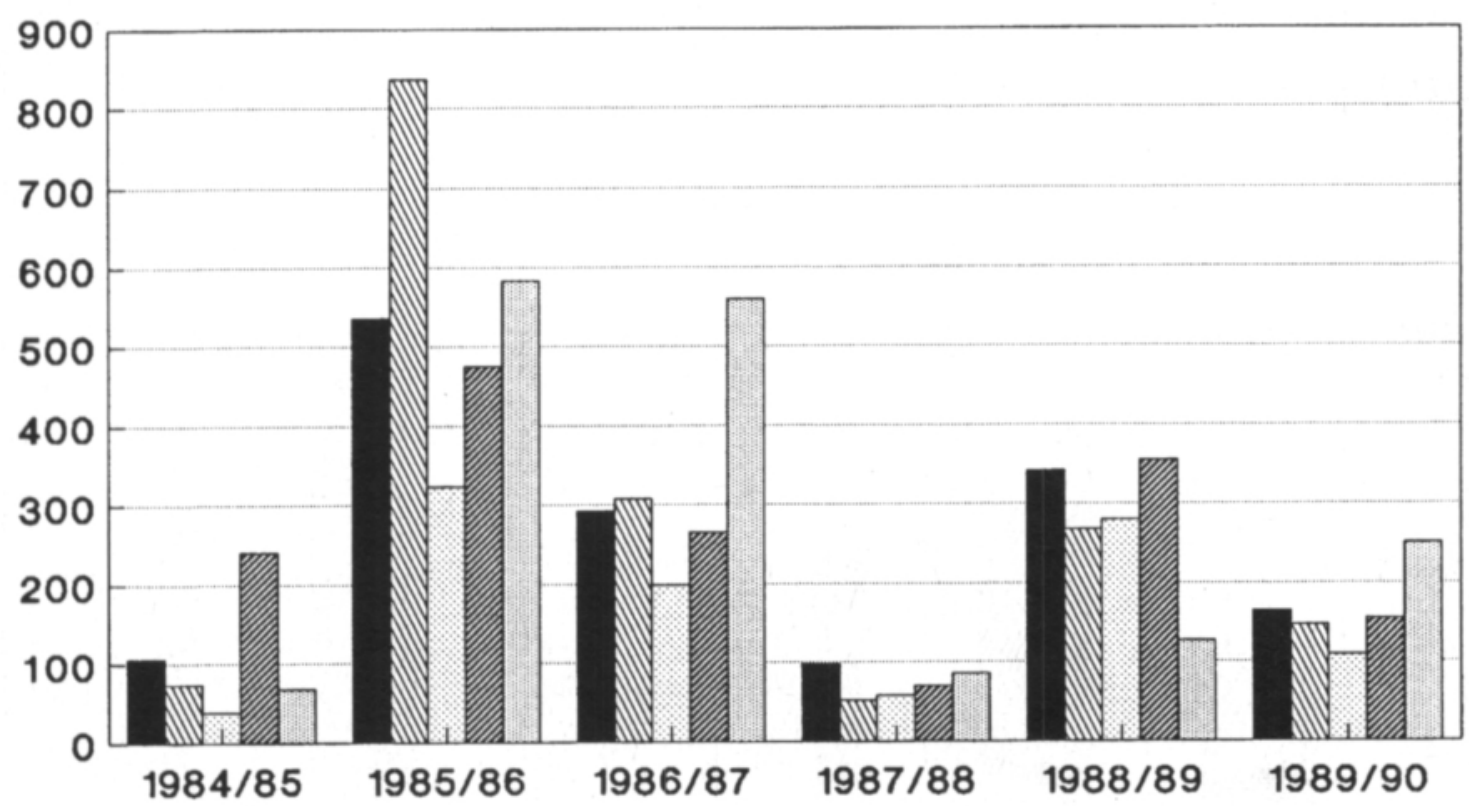

LOBO

AMIV KANELI

ATLAS

TRANSP.BL.

GYLLENKR.

Fig. 5. Numbers of ERM winter eggs/10 cm twig on five cultivars in a commercial orchard in winters 1984/85 through $1989 / 90$. 
Table 3. Correlation between numbers of pesticide sprays and numbers of ERM winter eggs. Correlation coefficients (r) and significance levels (sig.) according to Pearson correlation.

Correlations in

\begin{tabular}{|c|c|c|c|c|}
\hline \multirow{2}{*}{$\frac{\text { Sprays }}{\text { Number of: }}$} & \multicolumn{2}{|c|}{$\begin{array}{l}\text { All orchards } \\
\mathrm{N}=269\end{array}$} & \multicolumn{2}{|c|}{$\begin{array}{l}\text { Commercial orchard } \\
\mathrm{N}=226\end{array}$} \\
\hline & $\mathrm{r}$ & sig. & $\mathrm{r}$ & sig. \\
\hline Acaricidal sprays & 0.125 & 0.042 & 0.042 & NS \\
\hline Insecticidal sprays & 0.249 & 0.000 & 0.173 & 0.009 \\
\hline Fungicidal sprays & 0.287 & 0.000 & 0.216 & 0.001 \\
\hline All sprays together & 0.285 & 0.000 & 0.207 & 0.002 \\
\hline
\end{tabular}

flubenzimine were due to spraying too early and under rainy conditions.

The ERM winter egg density in diverse cultivars varied greatly from year to year, but no significant differences could be found when the two main cultivars were considered (Fig. 4). In a single orchard, the variation between cultivars was greater, and the ERM numbers on cultivars differed significantly (Fig. 5). The F-values and significance levels of the differences between the five cultivars were as follows:

$\mathrm{F}=9.75^{* * *}(1984 / 85), \mathrm{F}=4.06 *(1985 / 86)$,

$\mathrm{F}=3.17^{\circ}(1986 / 87), \mathrm{F}=2.74^{\circ}(1987 / 88)$,

$\mathrm{F}=6.90^{* *}(1988 / 89)$ and $\mathrm{F}=3.69^{* *}(1989 / 90)$.

\section{Discussion}

The method used in this study to estimate the numbers of ERM winter eggs resembles the standard method of IOBC (International Organization for Biological Control) for ERM winter egg estimation described by FAUVEL et al. (1978). This kind of method gives a relative estimate of the ERM winter egg abundance and is therefore suitable for comparison of the sequential series of samples taken in the same manner.

KARG and FREIER (1986) mention that a critical abundance of ERM winter eggs is between 100 and 250 eggs $/ 10 \mathrm{~cm}$ twig. This number of ERM winter eggs may lead to so high ERM numbers in spring that economic losses are possible. FrEIER and KARG
(1988) stated that a threshold of about 140 eggs/ $10 \mathrm{~cm}$ twig can be expected if 11 twigs out of 20 possess more than 100 eggs each. As no studies of the thresholds under Finnish conditions are available, the above German thresholds may be used for now as reference. In this study, only in the spring of 1986 did the mean number of ERM winter eggs exceed the threshold of 140 eggs $/ 10 \mathrm{~cm}$ twig. In the spring of 1988, none of the samples from individual orchards exceeded that threshold.

Increasing temperature resulted in higher ERM winter egg numbers. The temperature in August affects the generation that involves those females that lay winter eggs; thus favourable weather in August results in high winter egg numbers. The total effective temperature sum of the growing season is highly significant in determining the number of ERM generations and thus also the number of ERM winter eggs, if the effect of limiting factors is restricted.

Especially, if the ERM winter egg numbers are high, the importance of extremely low temperatures in winter should be taken into account when the need for early spring spraying against ERM is considered. The results of MACPHEE (1961) and Somme (1965) show that there are differences in cold hardiness between geographical strains of ERM. In this study, the lowest recorded temperature was $-36.7^{\circ} \mathrm{C}$, which is near the lowest 'supercooling point', $-37.2^{\circ} \mathrm{C}$, found in winter eggs of one strain of ERM by MACPHEE (1961) in 
Canada. Sømme (1965) determined $-33.2^{\circ} \mathrm{C}$ as the lowest supercooling point. The supercooling point is here defined as the temperature at which the freezing of eggs occurs at a rapid cooling rate; the mortality depends also on the duration of exposure to the low temperature as well as on the speed of the fall in temperature. MACPHEE (1961) proved that resistance to cold could be increased in the laboratory by selection. The Finnish ERM strains certainly possess a relatively high resistance to cold, as the lowest recorded temperatures in the apple growing area have been $-37.4^{\circ} \mathrm{C}$ in Piikkiö (1979) and - $32.9^{\circ} \mathrm{C}$ (1979) at Mariehamn (Åland). There are possibly slight differences in cold hardiness between the ERM strains in Åland and in the mainland.

The occurrence of predaceous phytoseiid mites (Acari: Phytoseiidae) was not recorded in this study. In Finland, the phytoseiid mite Typhlodromus pyri (Scheuten), used in integrated mite management (Collyer 1964, Wildbolz 1986), has been found to occur only in Åland in small numbers (TuOvinEN, unpublished). The detrimental effect of low winter temperatures on $T$. pyri would be necessary to study if resistant strains of the species were imported for biological control of ERM.

Rainfall and high humidity are known to increase the mortality of ERM (PUTMAN 1970). As the rainfall is often local, the precipitation should be observed in each orchard separately to attain more detailed knowledge of the effect of rainy weather on the ERM population density. However, the relatively clear negative correlation between the precipitation in May and ERM winter egg numbers in the following winter can be interpreted as the influence of rain on immature stages in conditions where leaves do not yet offer much shelter. In practice, it is advisable to consider the effect of rainy periods in spring by inspecting leaves for ERM larvae soon after hatching, especially if winter egg numbers were high but no early spring sprays were done. The negative correlations of precipitation in August and October with ERM winter egg numbers may be a sign of the effect of rainy weather on the last generation, hence the egg laying females, and on their egg laying intensity. In Finnish conditions, ERM begins to lay winter eggs in August and continues until late October (LisTo et al. 1939). The importance of rain as a factor that reduces egg laying would need more detailed studies.

The positive correlation of increasing number of pesticide sprays with ERM winter egg numbers leads to the same conclusion as in earlier studies: insecticide sprays kill many of the important natural enemies of ERM, and thus result in higher ERM density (KROPCZYNSKA and TUOVINEN 1988, TUOVINEN 1989). The use of acaricides and fungicides is closely related to insecticidal sprays as part of the general cultivation technique. The positive correlation of these sprays with ERM winter egg numbers more likely reflects the effect of intensive apple cultivation techniques than the special effect of the sprays themselves. However, the commonly used fungicide, bitertanol, may have a slightly increasing effect on ERM numbers, as the data of TuOvinen (1990) show, although the possible influence was not significant.

The particular weather conditions result in lower or higher ERM winter egg numbers, and generally this effect is not highly dependent on other conditions at the orchard level in commercial orchards, assuming that the general growing technique is not changed. A low total effective temperature sum of the growing period, low temperatures in August and a high total precipitation, all these occurred in 1987. These circumstances resulted in the lowest ERM winter egg numbers during the study period. In any particular orchard, variation of ERM winter egg numbers from year to year could be roughly predicted from the weather data for the previous growing season, assuming that the changes in general conditions, e.g. pesticide sprays, are inconsiderable. In particularly unfavourable climatic conditions like in 1987 the weather based prognosis is applicable in general.

The number and size of the samples needed for general ERM winter egg monitoring can be estimated according to the weather conditions in the preceding season. If the weather has been 
unfavourable for ERM, that is: high precipitation in May, August and/or in October together with low temperatures in August and/or the whole growing period, the need for monitoring (numbers of samples, size of sample) is less than after a 'normal' year. Consequently, after an unfavourable year, the need for early spring sprays is negligible. In an opposite situation, that is: low precipitation in May or in August and/or October together with high temperatures in August and/or the whole growing period, the need of monitoring is essential. In this situation monitoring may not need any accurate inspections, because the high numbers of ERM winter eggs are easily seen as red colour on branches. In 'normal' years, the orchard level monitoring is most important as weather based general prognosis is not reliable.

The high mortality of ERM winter eggs due to exceptionally low winter temperatures should be taken into account when the necessity of early spring spraying with mineral oil preparates is estimated. The viability of eggs should be checked if the lowest recorded temperatures are prolonged or repeatedly below $-25^{\circ} \mathrm{C}$, and the observed ERM winter egg abundance should be adjusted for the increased mortality.

\section{References}

COLlyer, E. 1964. A summary of experiments to demonstrate the role of Typhlodromus pyri Scheut. in the control of Panonychus ulmi (Koch) in England. Acarologia, Proc. First Intern. Congr. Acarology, Fort Collins, Colorado, USA, 1963: 363-371.

Croft, B. A. \& Brown, A. W. A. 1975. Responses of arthropod natural enemies to insecticides. Ann. Rev. Entomol. 20: 285-335.

Fauvel, G., Audemard, H., Rodolphe, F. \& Rambier, A. 1978. Le récensement des oeufs d'hiver de l'acarien rouge Panonychus ulmi (Koch) sur le pommier. I. Ann. Zool.-Ecol. Anim. 10: 461-482.

FreIER, B. \& KARG, W. 1988. Regressionsmodelle für die Schnellbonitur des Spinnmilbenbefalls in Apfelanlagen. J. Appl. Ent. 105: 48-52.

KARG, W. \& FreIER, B. 1986. Eine statistisch begründete Schnellbonitur zur Auswertung von Fruchtholzproben auf Wintereier der Obstbaumspinnmilbe für die Bestandesüberwachung im Apfelintensivanbau. Nachr.Bl. Pflanzenschutz DDR 40: 174-176.

KROPCZYNSKA, D. \& TUOVINEN, T. 1988. Occurrence of predatory mites (Acari: Phytoseiidae) on apple trees in Finland. Ann. Agric. Fenn. 27: 305-314.

LIENK, S.E. \& CHAPMAN, P.J. 1958. Effect of the winter temperatures of 1956-57 on the survival rate of European red mite eggs. J. Econ. Entomol. 51: 263.

Listo, J., Listo, E-M. \& Kanervo, V. 1939. Studies of the fruit tree red mite (Paratetranychus pilosus C. \& F.). (Summary). Valt. Maatalouskoet. Julk. 99: 1-143.

MACPHEE, A. W. 1961. Mortality of winter eggs of the European red spider mite Panonychus ulmi (Koch) at low temperature, and its ecological significance. Can. J. Zool. 39: 229-243.

McMurtry, J. A., Huffaker, B. C. \& Vrie, M. van de. 1970. Ecology of tetranychid mites and their natural enemies: a review. I. Tetranychid enemies: their biological characters and the impact of spray practices. Hilgardia 40: 331-390.

Post, A. 1962. Effect of cultural measures on the population density of the fruit tree red spider mite, Panonychus ulmi Koch (Acari: Tetranychidae). Tijdschrift over Planteziekten 69: 1-110.

PutMan, W. L. 1970. Effects of water and high humidity on the European red mite Panonychus ulmi (Acari: Tetranychidae). Can. Entomol. 102: 955-961.

Søмme, L. 1965. Changes in sorbitol content and supercooling points in overwintering eggs of the European red mite (Panonychus ulmi (Koch)). Can. J. Zool. 43: 881884.

- 1966. Mortality of winter eggs of Metatetranycus ulmi (Koch) during the winter 1965/66. Norsk Entomol. Tidsskr. 13: 420-423.

TUOVINEN, T. 1989. Chemical control of the European red spider mite Panonychus ulmi (Acari: Tetranychidae). I. Evaluation of flubenzimine. Ann. Agric. Fenn. 28: $317-$ 332.

- 1990. Chemical control of the European red spider mite Panonychus ulmi (Acari: Tetranychidae). II. Evaluation of clofentezine and hexythiazox. Ann. Agric. Fenn. 29: 195-215.

Veerman, A. 1985. Diapause. In: Helle, W \& Sabelis, M. W. (eds.). Spider Mites, Their Biology, Natural Enemies and Control. Vol. A, Elsevier, Amsterdam, p. 279-316.

WildBolz, T. 1986. Raubmilben als Spinnmilbenfeinde im Obstbau. Schweiz. Z. Obst-Weinb. 120: 433-435.

\section{Manuscript received July 1991}

Tuomo Tuovinen

Agricultural Research Centre of Finland

Institute of Plant Protection

SF-31600 Jokioinen, Finland 


\title{
SELOSTUS
}

\section{Säätekijöiden vaikutus hedelmäpuupunkin talvimunien runsauteen omenalla}

\author{
TUOMO TUOVINEN \\ Maatalouden tutkimuskeskus
}

Hedelmäpuupunkin talvehtivan kannan runsauden selvittäminen on hyödyksi seuraavan kevään torjuntatarvetta arvioitaessa. Arviointia varten tarvittavien oksanäytteiden tarkastus on aikaavievää. Tässä tutkimuksessa on selvitetty kasvukauden lămpötilan ja sadesumman vaikutusta hedelmăpuupunkin talvehtivan kannan suuruuteen sekä mahdollisuutta käyttää säätekijöihin perustuvaa runsausarviota apuna arvioitaessa vuosittaista näytteiden tarkastustarvetta. Lisäksi selvitettiin torjunta-aineiden käytön vaikutusta talvimunien runsauteen.

Hedelmåpuupunkkien talvimunien runsaus tutkittiin vuosina 1984-1989 kaupallisista hedelmätarhoista ja kotipuutarhoista kerättyjen oksanäytteiden $(\mathrm{N}=279)$ avulla. Tutkimusaikana kasvukauden tehoisat lämpösummat Piikkiössä olivat 1030-1564 päiväastetta ja touko-lokakuun sadesummat 289-562 mm. Elo-, heinä- ja kesäkuun sekä koko kasvukauden lämpösummien kasvu vaikutti hedelmäpuupunkin talvimunien määrää lisäävästi. Sen sijaan touko-, loka- ja elokuun sekä koko kasvukauden sadesummien kasvulla oli talvimunien mäăräă văhentävă vaikutus.

Kylmät talvet 1984/85 ja 1986/87 vaikuttivat hedelmäpuupunkin talvimunien kuoriutumiseen alentavasti 70 ja 26 \% verrattuna vuosien 1986 ja 1988 'normaalitalviin'.

Lämpö- ja sadesummia voidaan käyttää alustaviin arvioi- hin talvehtivien hedelmäpuupunkkien runsaudesta omenaviljelyksillä. Seuraavat yleistykset voidaan tehdä: 1) sateinen toukokuu ja elokuu ja/tai lokakuu sekä kylmä elokuu ja/tai koko kasvukausi johtavat vähäiseen talvimunien mäărăăn, 2) kuiva toukokuu ja elokuu ja/tai lokakuu sekä lämmin elokuu ja/tai koko kasvukausi johtavat suureen talvimunien määrään. Ensimmäisen vaihtoehdon toteutuessa tarve tarkkailla talvimunien määrää on pienempi kuin 'normaalina' vuonna. Toisaalta toisen vaihtoehdon toteutuessa runsas talvimunien määrä on helposti havaittavissa ilman erityistä näytteenottoa. Jos kumpikaan vaihtoehto ei toteudu, tällaisena 'normaalina' vuonna on syytä tehdä tarkempi havainnointi näyteoksista.

Hyönteisten ja omenaruven torjunta-aineiden käyttökertojen kasvu vaikutti hedelmäpuupunkin talvimunien määräă lisäävästi. Jos torjunta-aineita ei käytetä lainkaan, ei hedelmäpuupunkin torjuntakaan ole tarpeen.

Tarhakohtaisesti hedelmäpuupunkin talvimunien runsaudet vaihtelevat huomattavasti. Myös omenalajikkeiden välillä esiintyi suuria eroja, mutta tåssă tutkimuksessa yleisimpien lajikkeiden Lobon ja Punakanelin vălillă ei ollut merkitseviä eroja. Muiden lajikkeiden osalta tilastollista vertailua ei tehty aineiston hajanaisuuden vuoksi. 